\title{
Possible Secretion of the Oviposition-Inducing Factor after Oviposition of the Terminal Egg of a Clutch Sequence in the Domestic Fowl
}

\author{
Tadashi NAKADA and Kousaku TANAKA* \\ Department of Animal Science, University of the Ryukyus, \\ Nishihara-cho, Okinawa-ken, 903-01 \\ * Department of Animal Science, Kyushu University, Fukuoka-shi 812
}

(Received September 18, 1989)

\begin{abstract}
To estimate whether the oviposition-inducing factor (OIF) is released other than at the time of oviposition, spontaneous oviposition of the terminal (Ct) egg of a clutch sequence was prevented by ligation of the vagina for a short period. Of 51 hens, 17 laid their retained $\mathrm{Ct}$ eggs on the day of operation, 25 laid about $1 \mathrm{hr}$ before $\mathrm{C} 1$ ovulation the next day after the operation, and 9 laid on the third day in association with ovulation. When the oviposition of the midsequence (Cs) egg and the acceptance of the ovum destined to ovulate next were prevented simultaneously, five out of 20 hens laid their eggs immediately or soon after the removal of the vaginal ligature. All of the remaining 15 hens held their Cs eggs for a night and laid the next day in coincidence with ovulation. From the present experimental results, it is suggested that an increased secretion of OIF may occur in the afternoon of Ct oviposition but may not occur after Cs oviposition.
\end{abstract}

Jpn. J. Zootech. Sci., 61 (5) : 428-4321990

Key words : oviposition factor, prevention of oviposition, ovulation

In the poultry industry, it is well known that economical loss as a result of soft-shelled (SS) eggs laid prematurely is a significant problem. Recent studies based on the observation of 81 million commercial layers have shown that the stimulate of total eggs cracked or lost prior to reaching their destination ranged from 13 to $20 \%{ }^{1)}$. HUGHES and PARKER ${ }^{2)}$ reported that a majority of SS eggs was laid between 5 p.m. and 9 p.m.. Hewitr $^{3)}$ and Polin and Sturkie ${ }^{4>}$ suggested that the cause of SS eggs might be attributed to the premature laying of eggs, although SS eggs were reported to be caused by a lack of calcium utilization within the uterus rather than premature oviposition ${ }^{5)}$.
At present, it has been well documented that arginine vasotocin (AVT) ${ }^{6-10)}$ and prostaglan$\operatorname{dins}^{11-13)}$ are closely related to cause oviposition in the domestic fowl. These active substances are arbitrarily symbolized as OIF (Oviposition-inducing factor). However, little information is available as to whether any increase in the plasma OIF takes place elsewhere other than at the time of the OIF surge occuring just before spontaneous oviposition or shortly before ovulation of the first (C1) egg of a clutch $^{9,14,15,17)}$.

The present study was conducted to estimate whether such OIF is released during the laying cycle. 


\section{Materials and Methods}

Birds from a commercial hybrid egg-laying stock were used. They were maintained in individual laying cages fitted with automatic oviposition recorders and were exposed to a 14-hr photoperiod (0500 to 1900). All hens selected for the present study exhibited clutches of more than 4 eggs, with a pause of only a single day for at least 3 weeks.

\section{Experiment I}

The following procedure was employed in the surgical prevention of oviposition. The vagina was losely ligated through an incision made in the left abdominal wall just before the expected time of oviposition of the terminal $(\mathrm{Ct})$ egg of a clutch, followed by closing of the incision. Within $3 \mathrm{hrs}$ after the ligation, the thread placed around the vagina was removed.

\section{Experiment II}

Shortly before the expected time of oviposition of an intrasequential (Cs) egg (C2 or C3), the vagina and the infundibulum were ligated simultaneously through a left abdominal incision. The thread placed around the vagina was removed within $3 \mathrm{hrs}$ after the operation while the ligature of the infundibulum was left to prevent the reception of the ovum destined to ovulate next. By this treatment, the uterine egg was retained in the uterus following removal of the vaginal ligature with some exception.

The oviposition time of the retain egg was recorded and arranged every $1 \mathrm{hr}$-interval. All hens were autopsied within a few hours after laying of the retained egg.

The significance for the percentage of the hens laid retained eggs were determined by the the $\chi^{2}$ test.

\section{Results}

\section{Experiment I}

A total of 51 hens were operated on and the incidence of the retained $\mathrm{Ct}$ eggs laid at various

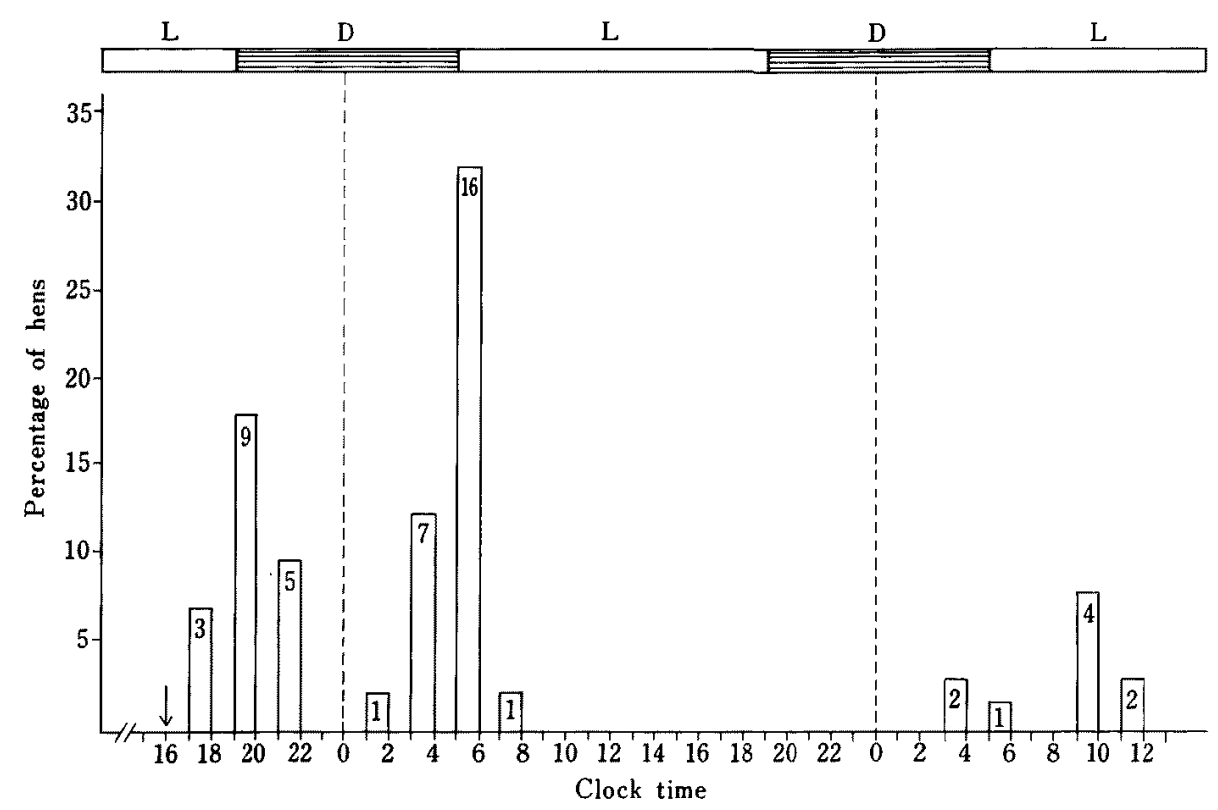

Fig. 1. Oviposition time and number of hens laid retained Ct egg

The arrow indicates the time of removal of the vaginal ligature. Figures inside columns indicate the number of hens laid retained egg. L : light period. $\mathrm{D}$ : dark period. 


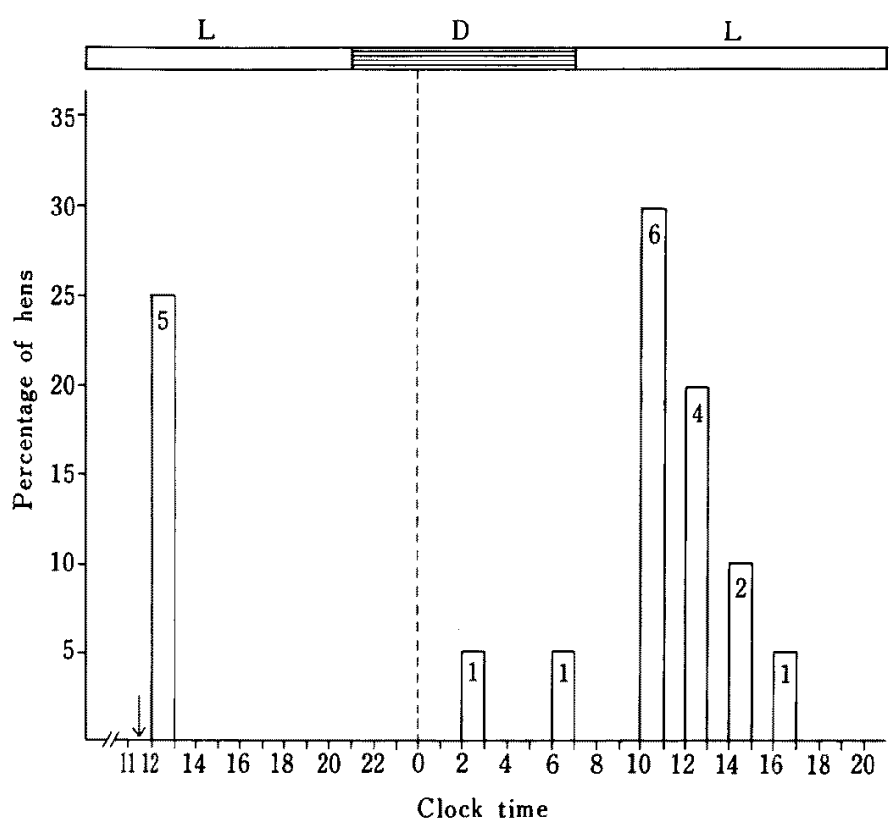

Fig. 2. Oviposition time and number of hens laid retained Cs egg

The arrow indicates the time of removal of the vaginal ligature. Figures inside columns indicate the number of hens laid retained egg. L : Light period. D : dark period.

times is shown in Fig. 1. Of the total hens, $17(33.3 \%)$ laid their retained eggs between 1700 -2200 on the operation day in which the percentage of hens which laid between 1900-2000 was higher than the others. No ovulation was found in any of these hens.

On the other hand, 25 hens laid their retained Ct egg between 0200-0800 the next day after the operation in which majority of hens (16), significant at 5\% level, laid between 0300-0600. At autopsy, $\mathrm{Cl}$ ovulation had occurred in all hens except in one which laid the retained egg at 0200 . The average interval between the oviposition of the retained $\mathrm{Ct}$ egg and $\mathrm{Cl}$ ovulation was about $1 \mathrm{hr}$, which was estimated from the position of the $\mathrm{Cl}$ ovum present in the oviduct.

The remaining 9 hens held their Ct eggs for more than $35 \mathrm{hrs}$ and laid between $0300-1200$ (see Fig. 1). The postmortem examination of these hens revealed that ovulation had occurred in association with the oviposition of the retaind $\mathrm{Ct}$ egg in all cases.

Experiment II

Of the total 20 hens, 5 laid their uterine eggs immediately or soon afer removal of the vaginal ligation (Fig. 2). The remaining 15 hens held their eggs (C2 or $\mathrm{C} 3$ ) until the next day after the operation. At autopsy, two internally ovulated ova, one within the period of vaginal ligation and another on the day of the oviposition of the retained egg, were found in the abdominal cavity in all hens except in one which laid the retained egg at 0200 and contained an ovum probably ovulated the preceding day (on the day of operation).

\section{Discussion}

It is noteworthy that the pattern of oviposition times of the retained $\mathrm{Ct}$ eggs on the operation day (Fig. 1) was fundamentally similar to the observations by several workers ${ }^{2,16)}$ 


\section{Secretion of Oviposition Inducing Factor}

based on the study of prematurely laid SS eggs. From the present results, it is suggested that some amount of OIF may be released in the afternoon of the spontaneous $\mathrm{Ct}$ oviposition but may not take place after Cs oviposition. It is also suggested that such increased OIF, if any, may act as a safety mechanism which forces out the $\mathrm{Ct}$ egg when its oviposition is accidently affected by physiological disorder. In addition, it is reasonable that the oviposition of the retained Cs egg did not occur in the afternon, suggesting that no OIF is released during egg formation in intact hens.

On the other hand, the hens with one exception laid their retained $\mathrm{Ct}$ eggs in association with $\mathrm{Cl}$ ovulation the next day after ovulation (Fig. 1), assuming that OIF was released prior to $\mathrm{C} 1$ ovulation. In this connection, there is evidence that a significant increase of plasma AVT occurs shortly before C1 ovulation ${ }^{9,17}$.

In Experiment II, one fourth of the Cs eggs were laid soon after the removal of the vaginal ligature. This prompt reaction was unexpected because no such event was observed in the case of the hens with $\mathrm{Ct}$ egg as mentioned above. The cause of this phenomenon is unknown at present.

Collectively, it is suggested that a considerable amount of OIF may be secreted after spontaneous $\mathrm{Ct}$ oviposition but are not secreted during egg formation. However, measurement of plasma OIF should be necessary before making a definitive conclusion about the secretion of OIF following $\mathrm{Ct}$ oviposition.

\section{References}

1) Roland, D.A., Poult. Sci., $67: 1801-1803.1988$.

2) Hughes, B.L. and J.E. Parker, Poult. Sci., $50 ; 1509$ 1511. 1971.

3) Hewitr. E.A., J. Am. Vet. Med. Assoc., $95: 201-210$. 1939.

4) Polin, D. and P.D. Sturkie, Poult. Sci., 34: 11691170. 1955.

5) Roland, D.A., D.J. Holcombe and R.H. Harms, Poult. Sci., 56 : 1232-1236. 1977.

6) TANAKA, K. and S. NaKaJo, Endocrinology, $70: 453$ 458. 1962.

7) SturkiE, P.D. and Y.C. LIN, J. Endocrinol, $35: 325-$ 326. 1966.

8) Niezgoda, J., J. RzASA and Z.EwY, J. Reprod. Fert., $35:$ 505-509. 1973.

9) Tanaka, K., K. Goto, T. Yoshloka, T. Terao and O. KogA, British Poult. Sci., $25: 589-595.1984$.

10) Shimada, K., N. Saito, K. Itogawa and T.I. KolKe, J. Reprod. Fert., $80: 143$-150. 1987.

11) Hertlendy, F., D.M. Olsen. H. Todd, R.W. Hammond, M. Toth and G. Asboth, in Reproductive Biology of Poultry (Cunningham, F.J., P.E. Lake and D. HewitT eds) 89-British Poultry Science Ltd. 1984.

12) Olsen, D.M., K. Shimada and R.J. Etches, Biology of Reproduction, $35: 1140-1146.1986$.

13) ShIMAdA, K., D.M. OlSEN and R.J. ETCHes, Biology of Reproduction, 35 : 1147-1153. 1986.

14) Nakada. T. and K. Tanaka, Jpn. Poult. Sci., Fall Supplement, 10:5, 1973.

15) TANAKa. K., T. NAKAda and O. Koga, Jpn. Poult. Sci, 19 : 124-125. 1982.

16) Hester, P. Y., E.K. Wilson, F.W. Pierson and I. FabiJansKa, Poult. Sci., 59 : 2336-2341. 1980.

17) Shimada, K., H.L. Nelson and T.I. Kolke, General and Comparative Endocrinology, 64 : 362-367. 1986. 


\title{
産卵鶏においてクラッチ最終卵の放卵後放卵誘起因子 （OIF）の分泌の可能性
}

\author{
仲田正・田中耕 作* \\ 琉球大学農学部, 沖縄県西原町 903-01 \\ * 九州大学農学部, 福岡市 812
}

\begin{abstract}
放卵誘起因子（OIF）が自然の放卵時期以外においても放出されているかどうかを調へるため，クラ ッチ最終卵 $(\mathrm{Ct})$ の放卵直前胵部を短時間結禁し自然放卵を阻止した。.この結果，51羽のうち 17 羽に おいては結紫処置当日， 25 羽に扔いて翌日のクラッチ第 1 卵 (C 1) の排卵の約 1 時間前, 残りの9羽 は同処置後 3 日目に Cs 卵（C1 と Ct を除く連産内の卵）の排卵之同時期にそれぞれ放卵された。一 方，Cs 卵の放卵直前に䐋の短時間結禁と同時に，万斗部を結禁し，次の予定排卵の卵が卵管内へ取り

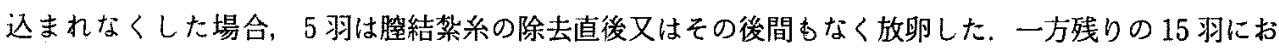
いては，処置当日に放卵は行なわれず，すべて翌日の Cs 卵の排卵之同時期に行なわれた。これらの結 果加ら，Ct 放卵当日の午後 OIF が放出されるが，畉形成中にはこれの放出は起こらないものと推定 された。
\end{abstract}

日童会報，61(5)：428-432，1990 